\title{
Firm Funding and Investment under Bank Credit Control Policy: Evidence from China
}

\author{
Xiaochen $\mathbf{F u}^{1}$
}

\begin{abstract}
Using the 2014 China Banking Regulatory Commission (CBRC) credit control policy as a quasi-natural experiment, this paper demonstrates that credit supply contraction leads to a significant reduction in firm's external funding, cash holding, and investment. Analysis of both loan-level and corporate-level data reveal that new bank loans issuance of targeted firms dropped significantly after the regulation. State-owned banks are identified as the main policy implementer. By instrumenting the change of loans issuance with the policy shock, I further discover the amplifying effect of large declines in bond issuance and trade credit for the targeted firms. Cash holdings were used to cushion the financing gap. Investment dropped and inefficient investment increased due to the shock. Interestingly, whereas such impacts were significant for non-state owned enterprises, state-owned enterprises (SOEs) were barely affected. Overall, I conclude that the lending control policy led to less capital resources allocated to non-SOEs but not SOEs.
\end{abstract}

JEL classification numbers: G21, G28, G32, G38.

Keywords: Bank lending, Firm funding, Firm investment, SOBs, SOEs, Credit policy, Credit rationing.

${ }^{1}$ PBC School of Finance, Tsinghua University.

Article Info: Received: April 24, 2021. Revised: May 16, 2021.

Published online: May 21, 2021. 


\section{Introduction}

Credit policy plays an important role in China's financial system (K. Chen and Zha, 2018). During the past decades, the Chinese government has frequently used credit policy, including aggregate bank loans control and loan quotas, to redirect loans into preferable (or out of unfavorable) industries, regions, and certain types of enterprises. The logic behind the policy design is that by adjusting capital constraint of targeted firms, the government can influence their investment and output accordingly. In many cases, credit policy is used as solutions to the problem of externalities, such as cutting the overproduction of polluting firms. The dominance of the state-owned banks (SOBs) and their close ties to the government secure an efficient transmission channel for the execution of credit policy.

In 2014, China Banking Regulatory Commission (CBRC) ${ }^{2}$ announced the "Key Evaluation Indicators for the Implementation of Green Credit", urging commercial banks to control their lending to 29 industries (Table 1). The policy was unforseen by commercial bankers and strictly executed by the banking system. I use this policy as an exogenous credit supply shock and estimate its impact on targeted firm's funding and investment.

Three factors motivated my research. First, while credit policy plays an important role in today's Chinese economy, we still know little about its transmission mechanism and real economy impacts. In what way and to what extent does the credit policy affect the behavior of banks and targeted firms? Is the policy tool effective and efficient in terms of directing capital to favorable entities? Are there any side effects overlooked? Up to date, few papers study these topics and the questions are still left open. This paper fills the research gap and gives answers. By using a typical and influential CBRC credit policy change, I present the interesting interactions between government, banks, and firms following the policy shock, and draw the roadmap of the credit policy transmission channel for the first time.

Second, the relationship between capital supply and corporate financial policies has always been the central topic for the corporate finance literature. Compared with higher funding costs, limited funding quantity (e.g. credit rationing) are more prevalent as the representation of financial constraints, especially in developing countries (Almeida and Campello, 2002). Although there is a large theoretical literature about how external funding supply influences a firm's debt financing decision (Diamond, 1984); (Holmstrom and Tirole, 1997), empirical researchers usually face the challenge to separate capital supply changes from capital demand changes, as both always move simultaneously. One solution to the problem is to take advantage of exogenous policy shocks to track the impact of capital supply changes (Banerjee and Duflo, 2014); (Berg, 2018); (Lemmon and Roberts, 2010). In China's case, recent literature rigorously examines the impact of the 4 trillion RMB stimulus package in 2009-2010 on firm borrowing and investment (Liu et al.,

2 In 2018, China Banking Regulatory Commission (CBRC) was dismantled, and its responsibilities was transferred to the newly formed China Banking and Insurance Regulatory Commission (CBIRC). 
2016), but the monetary expansion affects all firms in the economy. By utilizing an exogenous, sector based capital supply contraction shock, this paper provides emerging market evidence for the relationship between capital supply and corporate financial policies.

Third, the differential financial access of SOEs and non-SOEs are specifically important for Chinese economic studies. Chinese SOEs are generally less productive yet receive more loans from banks than non-SOEs (Hsieh and Klenow, 2009). It has been believed that banks' preferential lending led to capital misallocation and dragged China's economic growth (Firth et al., 2009), which forms the basis for some influential macroeconomic studies depicting the Chinese economy (Song et al., 2011). Thus, it is important to understand the role of firm ownership in the credit policy transmission process. Do state owned banks (SOBs) and non-SOBs react differently to the policy? Do banks treat SOEs and non-SOEs equally when achieving the policy goal? Does the CBRC regulation exacerbate or alleviate the country's financing structural problem in terms of firm ownership discrimination? All of these questions are carefully examined in this paper. I show that after the regulation, SOBs reacted actively by lending less to non-SOEs from targeted industries, leading to reduced bond borrowing, trade credit, cash holding and investment of the non-SOEs, while targeted SOEs were barely affected. Overall, the financial supply gap between SOEs and non-SOEs is widened after the credit control policy. This structural side effect of regulatory credit control policy is discovered for the first time, which is worth noting for future policymaking.

The paper is organized as follows. Section 2 presents the policy shock background and literature review. Section 3 describes data sources, empirical strategies, and analytical results. Section 4 addresses two identification concerns and presents a placebo test. Section 5 summarizes key findings of this research, discusses policy implications, and points out possible future research directions.

\section{Background and Hypothesis Development}

\subsection{The CBRC sector credit control regulation in $\mathbf{2 0 1 4}$}

Credit policy plays an important role in China's financial system. Chen and Zha define the Chinese government's financial policies as "a set of credit policy, monetary policy, and regulatory policy" (Chen and Zha, 2018). Like many developing countries, Chinese government frequently uses credit policy, including aggregate bank loans control and/or quota, to redirect loans into preferable (or out of unfavorable) industries, regions, and certain types of enterprises such as small and medium enterprises. By adjusting the capital constraint of targeted firms, the government aims to influence affected firms' investment and output. Many times, credit policy is applied to solve the problems of externalities, such as cutting the overproduction of polluting firms, providing necessary financial support for SMEs, and financing technological innovations.

Credit policy as a financial policy tool is exceptionally effective and frequently adopted in China due to the dominance of state-owned banks (SOBs) and their close 
ties to the government. By the end of 2016, the state-owned "Big Four Banks", or the ICBC, $\mathrm{ABC}, \mathrm{BOC}$, and $\mathrm{CCB}$, altogether consist of $40 \%$ of the whole banking sector asset size. In 2016, 46\% of loans in China were initiated by the Big Four Banks. Furthermore, the central government appoints high-level management officers, many of whom have experience working in regulatory authorities or the central bank. Thus, the dominance of SOBs and their close ties to the government secures a fluent transmission channel for complicated policies, such as credit control regulation targeting a certain type of firms.

Table 1: Industries targeted by the CBRC credit control policy change

\begin{tabular}{|l|l|}
\hline Industry code & \multicolumn{1}{|c|}{ Industry name } \\
\hline 1713 & Cotton printing, dyeing and finishing \\
\hline 1723 & Wool dyeing and finishing \\
\hline 1733 & Flax dyeing and finishing \\
\hline 1743 & Silk printing, dyeing and finishing \\
\hline 1752 & Chemical fiber dyeing and finishing \\
\hline 1910 & Leather tanning and processing \\
\hline 1931 & Fur tanning and processing \\
\hline 2211 & Wood pulp and Bamboo pulp manufacturing \\
\hline 2212 & Non-wood pulp and non-bamboo pulp manufacturing \\
\hline 2520 & Coking \\
\hline 2611 & Inorganic acid manufacturing \\
\hline 2612 & Inorganic alkali manufacturing \\
\hline 2613 & Calcium carbide \\
\hline 2614 & Methanol \\
\hline 2614 & Silicone monomer \\
\hline 2619 & Yellow phosphorus \\
\hline 2621 & Nitrogen fertilizer manufacturing \\
\hline 2622 & Phosphate fertilizer manufacturing \\
\hline 2651 & Calcium carbide process PVC \\
\hline 2911 & Bias tires \\
\hline 2911 & Bicycle tyre \\
\hline 3011 & Cement manufacturing \\
\hline 3041 & Plate glass manufacturing \\
\hline 3099 & Polysilicon \\
\hline 3110 & Ironmaking \\
\hline 3120 & Steelmaking \\
\hline 3150 & Ferroalloy smelting \\
\hline 3216 & Aluminium smelting \\
\hline 3731 & Metal ship building \\
\hline
\end{tabular}

Notes: The Table presents the 29 industries targeted by the 2014 CBRC credit control regulation. The industry code is the national economic code defined by China National Bureau of Statistics. 
A sector credit control policy initiated in 2014 offers a valuable opportunity for studying the effects of credit policy on banks and firms. Chen and colleagues show that during the stimulus period of 2009-2010, credit was asymmetrically allocated in favor of the heavy sector and exacerbated the "high pollution, high energy consumption, and overcapacity problem" (Chen et al., 2016). To mitigate the problem, the Chinese government sought sector-wise credit control policies for solutions. In 2014, CBRC announced the "Key Evaluation Indicators for the Implementation of Green Credit", which identifies 29 industries and urges the commercial banks to reduce their loan issuance to these industries. Table 1 presents the 29 industries included in the regulation. To ensure that banks fulfill the credit control goal, CBRC required all banks to submit the annually lending control statistic report to the commission.

An important question to address concerns the exogeneity of the policy change event with respect to the credit demand for the affected industries. What drives the CBRC to impose the credit control policy in 2014? According to the document of the regulation notification, environment protection was the main purpose of the rule. $^{3}$ Interviews with bankers confirmed that the policy change in 2014 was unexpected. According to the bankers, by the time of the policy announcement, credit demand of the targeted industries was still strong and branches struggled to control the total loan scale. Bank managers had to choose between clients from targeted sectors to meet the policy goal. ${ }^{4}$ All these facts suggest that CBRC's new rule was primarily driven by environmental concerns, as opposed to anticipated declines in credit demand for targeted industries.

\subsection{Bank reaction to the $\mathrm{CBRC}$ credit control regulation}

Chinese commercial banks typically lend a credit loan in three steps. In the first step, client managers from local branch finish and submit the due diligence report to the Credit Approval Department. If the credit amount is small, the Credit Approval Department of local branch would have the authorization to review the loan application; otherwise, the application would be reviewed by the Credit Approval Department from higher level authority, or even by the headquarter. In the second step, the Credit Approval Department review the due diligence report and decide the final credit line amount based on firm information. In the third step, the firm draws the credit line whenever it needs, and the Credit Management Department would be responsible for the loan collection monitory.

According to interview with commercial banks staff, banks executed CBRC's 2014 credit control policy mainly in three ways. First, the Credit Management Department would label the 29 targeted industries as "exit" or "lend with caution"

\footnotetext{
${ }^{3}$ In the "Notice on the issuance of the Key Evaluation Indicators for the Implementation of Green Credit", the CBRC claims that the policy purpose is to encourage banks to promote green credit development. (http://zfs.mee.gov.cn/hjjj/gjfbdjjzcx/lsxdzc/201507/t20150716_306761.shtml)

4 According to interviews with staff from Credit Management Department and Corporate Finance Department of two of the Big Four Banks.
} 
in the annual industry credit guideline, transmitting the information of lower credit approval possibility to client managers. Second, for each provincial branch, the Credit Approval Department would set a ceiling for the total lending amount to targeted industries. If a provincial branch broke the ceiling amount, it would be punished by the headquarter in the quarterly branch performance evaluation, which is directly linked to the branch's payroll budget and leadership promotion. Finally, the Corporate Finance Department, which administers all corporate client managers, would also issue marketing guidelines advising managers to lend less to the targeted industries.

Stylized facts show that after the sector credit control regulation announcement, bank lending decisions changed significantly, especially for SOBs. Figure 1 compares the change of loan amount issued to targeted and non-targeted firms. It shows that after the policy, the growth of average loan amount issued to targeted firms slowed down compared to non-targeted firms.

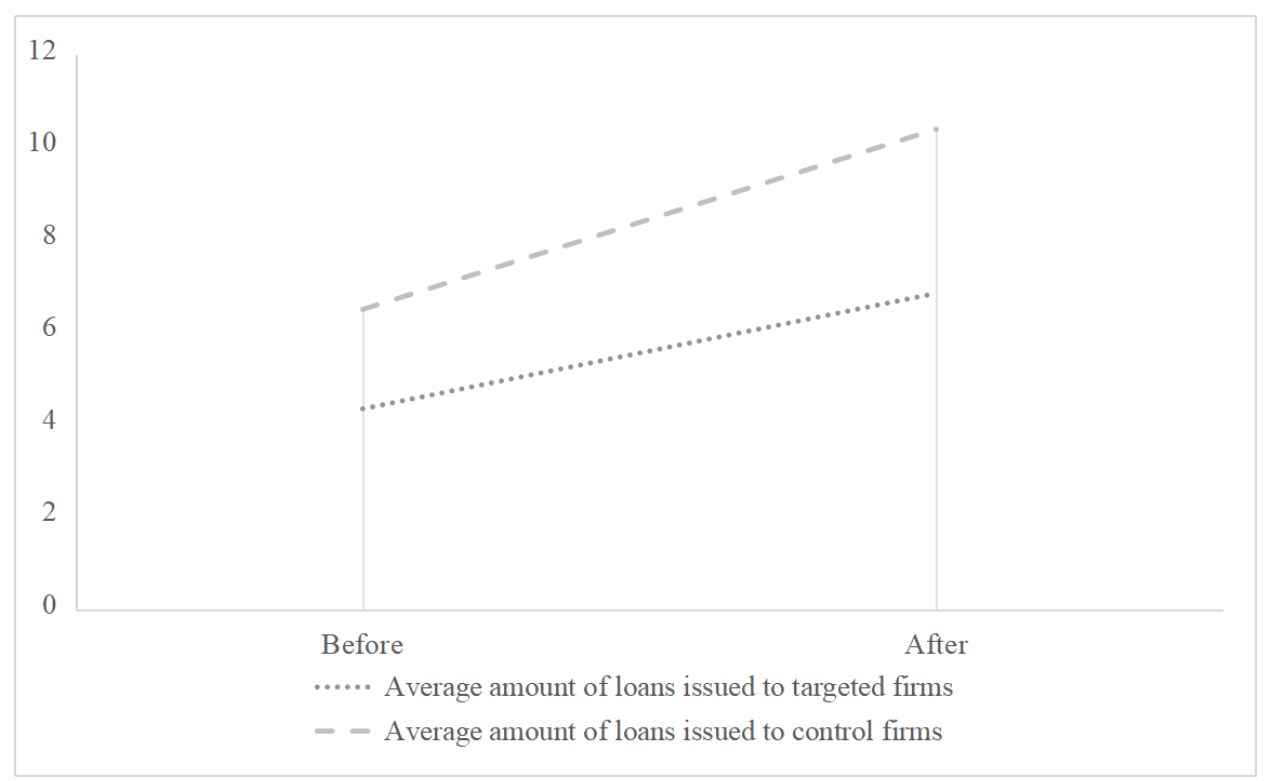

Figure 1: Loan amount change comparison (in 100 million RMB)

In Figure 2, I further divide the sample by bank ownership (i.e., SOBs vs. nonSOBs). Interestingly, the differential trends of loan amount growth for targeted and non-targeted firms are not so obvious for non-SOB loans. The stylized facts not only provide the intuition to use Difference-in-differences analysis as the main methodology in this paper, but also implies a possible unbalanced transmission channel of the policy in terms of bank ownership. 


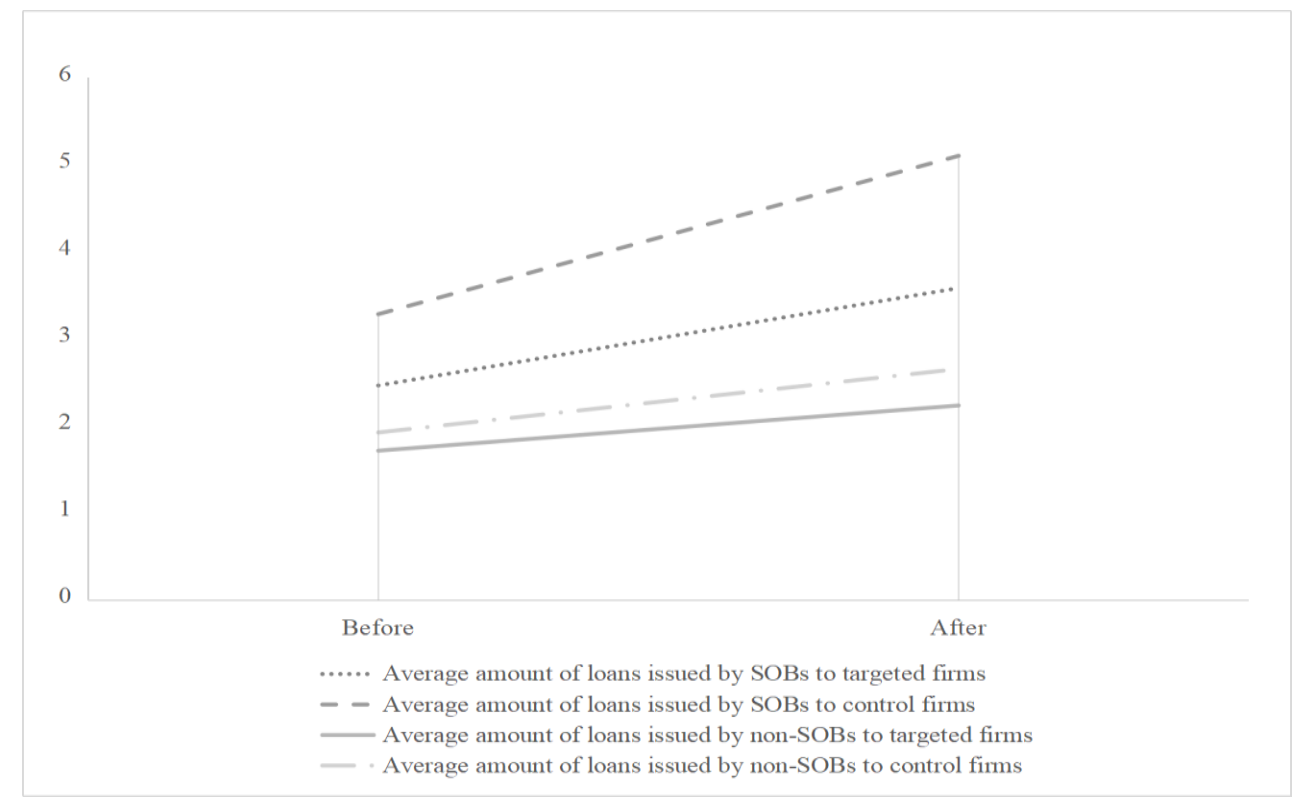

Figure 2: Loan amount change comparison by bank ownership (in 100 million RMB)

In the following sections, I explore the 2014 CBRC policy shock as an exogenous source of a differential drop in loans for firms from inside and outside the CBRC regulation list, and test whether there is a corresponding differential change in firm funding and investment.

\subsection{Literature review}

This paper focuses on the effect of credit control policy on bank lending, firm funding, and firm investment behavior. Here, I summarize how my work relates to two branches of literature, and in what ways my paper contributions to exiting literature.

First, a well-established strand of literature has explored firms' financing and investment reaction to loan supply shocks, which depends on firms' ability to access external finance. In the absence of market imperfections, a firm's financing policy is solely determined by its demand for debt, and capital supply has no impact on firms' investment decisions (Modigliani and Miller, 1958). However, given the imperfections in the capital markets, capital supply affects corporate financial policies significantly. Information asymmetry between borrowers and lenders calls for financial intermediaries that address capital rationing and adverse selection problems (Diamond, 1991); (Diamond, 1984); (Fama, 1985); (Holmstrom and Tirole; 1997).

A large empirical literature provides evidence that external finance significantly influences a firm's financing and investment decision (Faulkender and Petersen, 2006); (Leary, 2009); (Rajan and Zingales, 1995). Lemmon and Roberts study three 
simultaneous credit supply shocks on US below-investment-grade bond in 1989 . They find limited substitution from bond financing to alternative capital sources and estimates an almost one-for-one decline in net investment with the decline in net debt issuances (Lemmon and Roberts, 2010). Banerjee and Duflo study changes in access to the targeted lending program in India between 1998 and 2000. They show that extra credit was used to finance more production rather than to substitute for other forms of credit, and therefore prove that Indian SMEs were credit constrained (Banerjee and Duflo, 2014). Berg uses a lender cutoff rule by a major European lending institution to identify the cash holdings channel through which the funding shocks are transmitted to the firm investment (Berg, 2018). Relative to these studies, I explore an episode of credit control policy change in China and examine to what extent does this type of government intervention influence corporate funding and investment.

Second, an important strand of research has looked at Chinese banks' preferential credit policy toward SOEs and consequent capital misallocation. Allen et al. find that Chinese firms are severely financially suppressed and that non-SOEs are strongly discriminated in credit markets (Allen et al., 2005). Papers also show that Chinese banks inclined to lend to SOEs due to political reasons and state ownership of major banks (Boyreau-Debray and Wei, 2004); (Cull and Xu, 2003). Hsieh and Klenow find that the Total Factor Productivity (TFP) of SOEs is significantly lower than that of non-SOEs in China, yet more capital is still allocated to SOEs inefficiently (Hsieh and Klenow, 2009). Several influential macroeconomic papers depicting the Chinese economy, are based on the assumption that Chinese banks prefer to lend to SOEs (Song et al., 2011).

Considering the fact that banks' preferential lending towards SOEs, it is natural to develop and test the hypothesis that SOEs benefit more (or suffer less) after the credit control (or credit expansion) shock. Related to this topic, several papers study the differential impacts of Chinese monetary supply shocks on SOEs and non-SOEs. Researchers show that the episode of the 4 trillion RMB economic stimulation package impact in 2009-2010 led to more resources were allocated to SOEs(Lin et al., 2016); (Liu et. al, 2016). Chen, Li, and Tillmann examine monetary policy shocks between 2000 and 2016, and argue that SOEs generally suffer less from a policy tightening and benefit more from a policy easing (Chen et al., 2018). Different from these studies, my paper focuses on the impact of credit control shock rather than that of monetary policy shock.

This paper contributes to existing literature in three ways. First, it studies an exogenous credit supply shock targeting only a selected group of firms. While monetary shocks studied by prior literature generally affect the economy as a whole, the policy shock studied here benefits from its exogeneity and specificity, and thus produces more scientific results. Second, by utilizing the policy shock as the instrument variable, I identify the amplifying effect of the credit supply contraction on bond issuance and trade credit. These newly found channels help explain why the credit policy shock on firm cash holding and investment is so pronounced in China. Third, this paper not only examines the differential impact of the credit 
contraction on SOEs and non-SOEs, but also for the first time reveals the differential reaction of SOBs and non-SOBs to government's credit policy change. By doing so, the study provides a more comprehensive description of the policy mechanism through which the credit control regulation transmitted from the government to banks, from banks to corporate financing, then finally to the real economy (i.e. firm investment).

\section{Data and sample selection}

I use two datasets in this research. Table 2 presents the definition of key variables.

Table 2: Definitions of key variables

\begin{tabular}{|c|c|}
\hline Variable & Definition \\
\hline After & $\begin{array}{l}\text { a dummy variable equals to } 1 \text { for observations after year of } 2014 \\
\text { and } 0 \text { otherwise }\end{array}$ \\
\hline Treated & $\begin{array}{l}\text { a dummy variable equals to one if the firm falls into the credit } \\
\text { control industries }\end{array}$ \\
\hline Loan amount & The amount of a single bank loan (in 100 million RMB) \\
\hline $\begin{array}{l}\text { Long term bank loans } \\
\text { issuance }\end{array}$ & $\begin{array}{l}\text { The ratio of the change in firm's outstanding long term bank loans } \\
\text { to start-of-period assets. Long term loans are loans with maturity } \\
\text { longer than one year. }\end{array}$ \\
\hline $\begin{array}{l}\text { Total bank loans } \\
\text { issuance }\end{array}$ & $\begin{array}{l}\text { The ratio of the change in firm's outstanding total bank loans to } \\
\text { start-of-period assets }\end{array}$ \\
\hline Bond issuance & The ratio of the change in payable bonds to start-of-period assets \\
\hline Trade credit & $\begin{array}{l}\text { [(change in accounts payable }+ \text { change in accounts received in } \\
\text { advance }+ \text { change in notes payable) }- \text { (change in accounts receivable } \\
+ \text { change in accounts paid in advance + change in notes receivable) }] / \\
\text { start-of-period assets }\end{array}$ \\
\hline Equity issuance & $\begin{array}{l}\text { The ratio of (change incommon tock + change in deferred income } \\
\text { tax liability - change in retained earnings) to start-of-period assets }\end{array}$ \\
\hline Cash holdings & $\begin{array}{l}\text { The ratio of the change in the total of cash and marketable assets to } \\
\text { start-of-period assets }\end{array}$ \\
\hline Investment & $\begin{array}{l}\text { The ratio of (cash paid to purchase fixed assets, acquire intangible } \\
\text { assets and other long-term assets + cash paid to acquire subsidiaries } \\
\text { and other business units) to start-of-period assets }\end{array}$ \\
\hline Investment_2 & $\begin{array}{l}\text { The ratio of (cash paid to purchase fixed assets, acquire intangible } \\
\text { assets and other long-term assets - cash received from the disposal } \\
\text { of fixed assets, intangible assets and other long-term assets) to start- } \\
\text { of-period assets }\end{array}$ \\
\hline
\end{tabular}




\begin{tabular}{|l|l|}
\hline Investment_3 & $\begin{array}{l}\text { The ratio of(cash paid to purchase fixed assets, acquire intangible } \\
\text { assets and other long-term assets + cash paid to acquire subsidiaries } \\
\text { and other business units - cash received from the disposal of fixed } \\
\text { assets, intangible assets and other long-term assets - cash received } \\
\text { by selling subsidiaries and other business units) to start-of-period } \\
\text { assets }\end{array}$ \\
\hline Investment_4 & $\begin{array}{l}\text { The ratio of (cash paid to purchase fixed assets, acquire intangible } \\
\text { assets and other long-term assets + cash paid to acquire subsidiaries } \\
\text { and other business units - cash received from the disposal of fixed } \\
\text { assets, intangible assets and other long-term assets - cash received } \\
\text { by selling subsidiaries and other business units-Depreciation of } \\
\text { fixed assets, depletion of oil and gas assets, depreciation of } \\
\text { productive biological assets) to start-of-period assets }\end{array}$ \\
\hline Overinvestment & $\begin{array}{l}\text { The positive residual of investment regressed on a series of firm } \\
\text { characteristics (see section XX for details) }\end{array}$ \\
\hline Underinvestment & $\begin{array}{l}\text { The absolute value of the negative residual of investment regressed } \\
\text { on a series of firm characteristics (see section XX for details). }\end{array}$ \\
\hline Tobin' Q & The ratio of firm market value to replacement value \\
\hline Size & The log of total assets \\
\hline Directors & The log of numer of total directors on the board \\
\hline Leverage & The ratio of book value of debt to total asset \\
\hline OCF & The ratio of cashflow from operation to total asset \\
\hline ROA (Return on assets) & The ratio of revenue to asset \\
\hline ROS (Return on sales) & The ratio of revenue to sales \\
\hline Age & The log of firm age \\
\hline Shareholder 1 & Percentage share of stocks held by firm's largest shareholder \\
\hline Payout ratio & The ratio of payout dividend before tax to net profit \\
\hline SOE & $\begin{array}{l}\text { A dummy variable equals to 1 for observations with state owned } \\
\text { enterprises, and 0 otherwise. }\end{array}$ \\
\hline SOB & $\begin{array}{l}\text { A dummy variable equals to 1 for loans lent by 5 big state owned } \\
\text { banks and 0 otherwise. }\end{array}$ \\
\hline Growth & Year-on-year sales growth \\
\hline Tax & The log of firm's operational tax \\
\hline Risk & $\begin{array}{l}\text { Standard deviation of ROA over the three years before/after the } \\
\text { policy. }\end{array}$ \\
\hline &
\end{tabular}

Note: The Table presents the definitions of variables used in this paper.

The first dataset contains loan level information disclosed by listed firms. I use the dataset to examine the impact of credit control policy on bank lending behavior. The dataset begins with bank loan information from the Chinese Stock and Market Accounting Research (CSMAR) bank loan database, which collects loan information from public announcements made by listed firms. Loans with RMB currency between the year of 2012 and 2017 are included. I choose the time window 
between 2012 and 2017 to have a balanced time frame around the event date and to avoid the stimulus shock of 2008-2012. I keep loans lent by 16 major commercial banks, including 5 big state owned banks and 11 joint stock banks. ${ }^{5}$ I then exclude loans with more than one lenders, as well as loans lent by financial subsidiaries of these commercial banks. I further require that the public announcements describe the exact amount of loan, instead of a range of loan or just the amount of credit lines. I then merge the dataset with the firm-year dataset described below. This gives me a total of 9,151 loan level observations, involving 635 borrowers. Among them, 212 firms (disclosing 3,868 loans) are from the targeted industry of the 2014 CBRC lending control policy, while 423 firms (disclosing 5,283 loans) are not targeted by the policy. Table 3 presents summary statistics for the loan level dataset. The average amount of disclosed loans is 298 million RMB.

Table 3. Summary statistics of loan level dataset

\begin{tabular}{|l|c|c|c|c|c|c|}
\hline \multicolumn{1}{|c|}{ Variable } & $\mathbf{N}$ & Mean & SD & $\begin{array}{c}\text { 25th } \\
\text { quantile }\end{array}$ & median & $\begin{array}{c}\text { 75th } \\
\text { quantile }\end{array}$ \\
\hline Loan & 9,151 & 2.98 & 10.64 & 0.50 & 1.00 & 2.50 \\
\hline After & 9,151 & 0.52 & 0.50 & 0.00 & 1.00 & 1.00 \\
\hline Treated & 9,151 & 0.42 & 0.49 & 0.00 & 0.00 & 1.00 \\
\hline SOB & 9,151 & 0.52 & 0.50 & 0.00 & 1.00 & 1.00 \\
\hline ROA & 9,151 & 0.03 & 0.05 & 0.01 & 0.03 & 0.05 \\
\hline OCF & 9,151 & 0.04 & 0.21 & 0.01 & 0.05 & 0.08 \\
\hline Leverage t-1 & 9,151 & 0.21 & 0.14 & 0.10 & 0.20 & 0.29 \\
\hline Directors & 9,151 & 8.74 & 1.80 & 7.00 & 9.00 & 9.00 \\
\hline SOE & 9,151 & 0.18 & 0.39 & 0.00 & 0.00 & 0.00 \\
\hline
\end{tabular}

Notes: The Table reports the summary statistics of CSMAR loan level dataset. For variable definitions, see Table 2.

The second dataset, containing observations of listed firms' firm-year characteristics, is used to analyze the policy impact on firm's funding and investment. It begins with firm-year observations of all listed manufacturing firms' corporate characteristics, including financial reports, stockholder information, industry information, stock price etc. Data are collected from CSMAR's listed firms annual report database. I require non-missing data for total assets, investment, net loan issuance, market-to-book ratio, and retained earnings. I require positive total asset and positive equity. I trim all continuous variables at upper and lower $1 \%$ level. I also require firms to have constant industry classification throughout the entire 2012-2017 period. Each firm should contain at least one observation both before and after 2014. To construct SOE and non-SOE sub-samples, I further require firms

${ }^{5}$ The 5 big state owned banks are China Industrial and Commercial Bank, Agricultural Bank of China, Bank of China, China Construction Bank, China Bank of Communications. The 11 joint stock banks are China Citic Bank, China Everbright Bank, China Merchants Bank, Minsheng Bank, Pudong Development Bank, Huaxia Bank, Guangdong Development Bank, Ping An Bank, Zheshang Bank, Bohai Bank, and Hengfeng Bank. 
have constant ownership status throughout the entire 2012-2017 period.

Table 4: Summary statistics of key variables for the firm-year dataset

\begin{tabular}{|l|c|c|c|c|c|c|}
\hline \multicolumn{1}{|c|}{ Variable } & $\mathbf{N}$ & Mean & SD & 25th quantile & Median & 75th quantile \\
\hline Long term loan & 5,544 & 0.02 & 0.38 & -0.01 & 0.00 & 0.01 \\
\hline Total Loan & 5,544 & 0.06 & 1.36 & -0.02 & 0.00 & 0.06 \\
\hline TradeCredit & 5,544 & 0.00 & 0.52 & -0.03 & 0.00 & 0.03 \\
\hline Bond & 4,688 & 0.01 & 0.11 & 0.00 & 0.00 & 0.00 \\
\hline Equity & 5,544 & -0.01 & 1.34 & -0.03 & -0.01 & 0.02 \\
\hline Cash holding & 5,544 & 0.05 & 0.60 & -0.04 & 0.00 & 0.05 \\
\hline Investment & 5,544 & 0.09 & 0.48 & 0.02 & 0.05 & 0.09 \\
\hline Investment_2 & 5,544 & 0.07 & 0.37 & 0.02 & 0.04 & 0.08 \\
\hline Investment_3 & 5,544 & 0.08 & 0.46 & 0.02 & 0.04 & 0.09 \\
\hline Investment_4 & 5,544 & 0.05 & 0.37 & 0.00 & 0.02 & 0.06 \\
\hline Overinvestment & 3,233 & 0.39 & 0.30 & 0.15 & 0.33 & 0.57 \\
\hline Underinvestment & 2,308 & 0.32 & 0.27 & 0.12 & 0.26 & 0.45 \\
\hline After & 5,544 & 0.43 & 0.49 & 0.00 & 0.00 & 1.00 \\
\hline Treated & 5,544 & 0.34 & 0.47 & 0.00 & 0.00 & 1.00 \\
\hline ROS & 5,544 & 0.05 & 0.27 & 0.02 & 0.05 & 0.11 \\
\hline ROA & 5,544 & 0.04 & 0.07 & 0.01 & 0.03 & 0.06 \\
\hline Size & 5,544 & 22.2 & 1.22 & 21.4 & 22.0 & 22.9 \\
\hline Leverage t-1 & 5,544 & 0.16 & 0.14 & 0.04 & 0.14 & 0.26 \\
\hline Tobin's Q t-1 & 5,544 & 1.98 & 3.05 & 0.87 & 1.45 & 2.30 \\
\hline Casht-1 & 5,544 & 0.17 & 0.12 & 0.09 & 0.14 & 0.22 \\
\hline Director & 5,544 & 8.71 & 1.64 & 8.00 & 9.00 & 9.00 \\
\hline OCF & 5,544 & 0.05 & 0.22 & 0.01 & 0.05 & 0.09 \\
\hline SOE & 5,544 & 0.19 & 0.39 & 0.00 & 0.00 & 0.00 \\
\hline Growth & 5,542 & 0.38 & 9.29 & -0.06 & 0.07 & 0.22 \\
\hline Tax & 5,544 & 0.01 & 0.01 & 0.00 & 0.00 & 0.01 \\
\hline Risk & 5,544 & 0.04 & 0.15 & 0.01 & 0.02 & 0.05 \\
\hline Shareholder1 & 5,544 & 34.6 & 14.4 & 23.6 & 32.7 & 43.1 \\
\hline Payout ratio & 5,141 & 0.35 & 0.96 & 0.00 & 0.25 & 0.40 \\
\hline Nas & 5 & 5.45 & \\
\hline
\end{tabular}

Notes: The Table reports the summary statistics of the CSMAR firm level dataset. For variable definitions, see Table 2 .

It leaves me a total of 5,544 firms, including 1,040 SOE firms and 4,504 non-SOE firms. Table 1 lists the industries affected by the 2014 CBRC policy change. Since commercial banks usually use 2-digit sector code in sector credit guidance, I focus on results obtained from using 2-digit sector code for the treat and control group division. Table 4 presents summary statistics for the firm-year dataset. For the full sample, the yearly total bank loans issuance to total asset ratio is $5.60 \%$, the change of investment to the total asset is $9.38 \%$, and the average Tobin's Q is 1.98. These statistics are similar to results from earlier studies. 


\section{Empirical Strategy}

\subsection{Reduced form difference-in-difference estimates}

Since the credit control policy is an exogenous shock to the affected firms, I use DID method to gauge the impact of the credit supply contraction on firm financial policies. In particular, I measure the policy sensitivity from the following specification:

$$
Y_{\mathrm{it}}=\alpha+\beta_{1} \text { After }_{\mathrm{it}} \times \text { Treated }_{\mathrm{it}}+\beta_{2} \text { After }_{\mathrm{it}}+\beta_{3} \text { Treated }_{\mathrm{it}}+\beta_{4} X_{\mathrm{it}}+\varepsilon_{\mathrm{it}}
$$

where Yit is the variable of interest (e.g., loan amount, year-on-year change in new loan issuance, year-on-year change in investments, etc.).

After is a dummy variable equals 1 is an observation comes from the period after the policy started (i.e. after the year of 2014). Treated is a dummy variable equals 1 if an observation's firm falls into the listed industries specified by the CBRC. Xit represents the control variables, or a set of firm characteristics and bank characteristics, included in the regression. The coefficient of the interaction term AfterxTreated represents the policy impact on the dependent variables Yit.

First, I measure the impact of the lending control policy on bank lending behavior, by using bank loan amount as the dependent variable in regressing Equation (1). The control variables include a set of firm's characteristics related to bank lending decisions and firm borrowing needs, such as ROA (return on assets, as a proxy for firm's profitability), OCF (operation cash flow, as a proxy for firm's liquidity), Leverage (one year lagged), Directors (number of board members, as a proxy for firm's corporate governance), and SOE (dummy equals to 1 if a firm is state owned). The dummy variable representing the state ownership of the bank (SOB) is also included to control the differential lending decision making of SOBs and non-SOBs. To test the differential impact on lending of SOBs and non-SOBs, I divide the loan level sample into 4 sub-samples: loans from SOBs to SOEs, loans from SOBs to non-SOEs, loans from non-SOBs to SOEs, and loans from non-SOBs to non-SOEs, and examine whether the coefficients of the interaction term After×Treated are still significantly negative for all 4 sub-sample regressions.

Second, to measure the impact of the policy on firm's total borrowing from banks, I use the change of long term bank loan issuance and the change of total bank loan issuance as dependent variables. Long term loans are loans with maturity longer than one year. Following Firth et al. (2009), control variables include ROS (return on sales), Tobin' Q (ratio of firm market value to replacement value, a proxy for firm's investment opportunity), Cash (cash holding as a proxy for firm's internal financing ability), Director and OCF.

Third, I test the policy impact on firms funding other than bank borrowing. I use change of firm's new bond issuance, change of new equity issuance, change of new trade financing, and change of internal financing as dependent variables in Equations (1). Again, different groups of corporate characteristics are included as 
control variables. ${ }^{6}$

Finally, I examine the policy impact on firm investment decisions. The dependent variable is the change in net investment during the period. In the main analysis, I construct and examine the measure of change of investment as the ratio of (cash paid to purchase fixed assets, acquire intangible assets and other long-term assets + cash paid to acquire subsidiaries and other business units) to start-of-period assets. Following previous literature (Duchin et al., 2009), I apply 3 other proxies for investment for robustness tests. I test the policy impact on investment by examining whether the coefficient of the interaction term After $\times$ Treated is significantly negative. Following literature regarding corporate investment decisions (Duchin et al., 2009); (Julio and Yook, 2012), the regression also includes several firm characteristics that are associated with firm investment as control variables, including Tobin' Q, firm size, leverage, OCF, and firm age.

\subsection{Instrumental variable estimates}

Since the credit supply is not only influenced by the credit control regulation, I use 2SLS to measure the exogenous impact of the loan supply shock on interested variables, such as new bond issuance and investment. Following (Banerjee and Duflo, 2014); (Berg, 2018), I instrumented bank loan change with the policy shock. Assuming that the only exogenous impact of the policy on investment is due to its impact on credit supply, controlling for After and Treated, After $\times$ Treated is a valid instrument to identify the direct effect from the policy-driven credit decline on firm size. The 2SLS specifications are as follows. For stage one, I use Equation (2) to get the estimated change of bank loan issuance.

$$
\Delta \text { BankLoan }_{\mathrm{it}}=\alpha_{1}+\lambda_{1} \text { After }_{\mathrm{it}} \times \text { Treated }_{\mathrm{it}}+\lambda_{2} \text { After }_{\mathrm{it}}+\lambda_{3} \text { Treated }_{\mathrm{it}}+\varepsilon_{\mathrm{it}}
$$

Then for stage two, I regress change of interested variables, such as investment, on the estimated bank loan issuance from stage one as in Equation (2). The coefficient $\mu 1$ presents the direct impact of the policy change on firm investment.

$$
\Delta \mathrm{Y}_{\mathrm{it}}=\alpha_{2}+\mu_{1} \Delta \hat{B} \text { ankLoan }_{\mathrm{it}}+\mu_{2} \text { After }_{\mathrm{it}}+\mu_{3} \text { Treated }_{\mathrm{it}}+u_{\mathrm{it}}
$$

The IV estimates show the local effect of credit supply decrease on interested dependent variable.

${ }^{6}$ When examining the bond issuance change, control variables include firms size, tangibility, OCF, Tobin's Q, leverage, ROS, cash holding, and number of directors. When examining the trade credit issuance change, control variables include firms size, tangibility, OCF, Tobin's Q and leverage. When examining the new equity issuance change, control variables include firms size, Tobin's Q, leverage, ROS, cash holding, and firm growth. 


\section{Results}

\subsection{The impact of lending control policy on bank lending}

\subsubsection{Loan level bank loan amount}

First, I examine how the lending control policy affected bank lending decisions. I estimate Equation 1 using the single loan amount disclosed by the listed firms as the dependent variable. Table 5 presents the result. The coefficient of the interaction between After and Treated for the full sample is significantly negative (-0.705) at the $1 \%$ level. It means that due to the policy change, size of loans issued to targeted firms reduced by 70.5 million RMB on average, compared with non-targeted firms. When applying the regression to the sub-samples of loans issued to SOEs and nonSOEs, I find that the coefficient for the interaction between After and Treated is only significantly negative for non-SOEs sub-sample, while the coefficient for SOEs sub-sample is insignificant. These results show that after the lending control policy, commercial banks did reduce the loan amount issued to the targeted firms, and the policy-led loan amount reduction was only found in the non-SOEs. SOEs were barely affected. 
Table 5: Effect of the credit control policy on single loan amount

\begin{tabular}{|l|c|c|c|}
\hline \multirow{2}{*}{} & \multicolumn{3}{|c|}{ Bank loan amount } \\
\cline { 2 - 4 } & Full Sample & SOEs & Non-SOEs \\
\hline After×Treated & {$[1]$} & {$[2]$} & {$[3]$} \\
\hline & $-0.705^{*}$ & -0.475 & $-0.855^{* *}$ \\
\hline After & {$[-1.72]$} & {$[-0.27]$} & {$[-2.36]$} \\
\hline & $1.419^{* * *}$ & $3.539^{* *}$ & $1.123^{* * *}$ \\
\hline Treated & {$[3.95]$} & {$[2.01]$} & {$[3.61]$} \\
\hline & $-1.447 * * *$ & - & $-1.172^{* * *}$ \\
\hline SOB & {$[-5.46]$} & {$[-3.13]$} & {$[-4.14]$} \\
\hline & $1.459^{* * *}$ & $3.092^{* * *}$ & $1.142^{* * *}$ \\
\hline ROA & {$[7.21]$} & {$[4.20]$} & {$[5.91]$} \\
\hline & -0.097 & 17.205 & $-4.296^{* * *}$ \\
\hline OCF & {$[-0.04]$} & {$[1.44]$} & {$[-3.27]$} \\
\hline & $0.563^{*}$ & -5.526 & $0.792^{* * *}$ \\
\hline Leverage & {$[1.95]$} & {$[-0.83]$} & {$[4.15]$} \\
\hline & $2.587^{* * *}$ & $10.514^{* *}$ & 0.768 \\
\hline Directors & {$[2.85]$} & {$[2.89]$} & {$[1.28]$} \\
\hline & $0.769^{* * *}$ & $0.384^{* *}$ & $0.818^{* * *}$ \\
\hline SOE & {$[5.92]$} & {$[2.05]$} & {$[5.32]$} \\
\hline & $2.075^{* * *}$ & & \\
\hline Constant & {$[4.88]$} & & \\
\hline & $-5.402^{* * *}$ & $-3.232^{*}$ & $-5.121^{* * *}$ \\
\hline $\mathrm{N}$ & {$[-5.04]$} & {$[-1.87]$} & {$[-4.07]$} \\
\hline $\mathrm{R}^{2}$ & 9151 & 1672 & 7479 \\
\hline Adjusted $\mathrm{R}^{2}$ & 0.031 & 0.030 & 0.037 \\
\hline Chow test & 0.030 & 0.025 & 0.036 \\
\hline
\end{tabular}

Notes: The Table presents the policy impact on single loan amount. Here I use the Equation (1) OLS regression. The dependent variable is the single loan amount (in 100 million RMB). "After" is a dummy that equals 1 for observations from 2015-2017, and 0 from 2012-2014. "Treated" is a dummy variable equals 1 if the firm falls into the industries from Table 1. For other variable definitions, see Table 2. Leverage is one year lagged. T-statistics are in parentheses and computed using the robust standard error clustered by firm. *,**, and *** indicate the significance levels at $10 \%, 5 \%$, and $1 \%$ respectively.

\subsubsection{Results by bank ownership class}

Do SOBs and non-SOBs respond to the credit control policy in the same way? Figure 2 compares the relative change of loan amount issued by SOBs and nonSOBs toward the targeted and non-targeted firms. There is an obvious slowdown of loan amount growth issued by SOBs towards targeted firms, while non-SOBs seem to treat targeted firms and non-targeted firms similarly even after the policy shock. To better understand the policy transmission mechanism in terms of bank ownership, I apply the loan level amount regression to the following four sub-samples: loans issued by SOBs to SOEs, by SOBs to non-SOEs, by non-SOBs to SOEs, and by 
non-SOBs to non-SOEs. Columns 1 through 4 of Table 6 show the results of the four sub-sample regressions. Interestingly, the After $\times$ Treated coefficient (-1.241) is statistically significant only for the sub-sample of loans from SOBs to non-SOEs. The Chow test statistics for Column 1 and 2 is 10.96, significant at $1 \%$ level, which further supports the conclusion that SOBs treat SOEs and non-SOEs differently when transmitting the policy.

Overall, loan-level evidence shows that commercial banks curbed single loan amount growth after the policy shock, and SOBs were the major policy implementer. To meet the credit control goal urged by the policymakers, SOBs only suppressed its lending towards non-SOE clients, while kept lending to SOEs as before.

Table 6: Effect of the credit control policy on single loans amount: by bank ownership

\begin{tabular}{|c|c|c|c|c|}
\hline & \multicolumn{4}{|c|}{ Bank loan amount } \\
\hline & $\begin{array}{c}\text { From SOBs to } \\
\text { SOEs }\end{array}$ & $\begin{array}{c}\text { From SOBs to } \\
\text { non-SOEs }\end{array}$ & $\begin{array}{c}\text { From non- } \\
\text { SOBs to SOEs }\end{array}$ & $\begin{array}{c}\text { From non-SOBs } \\
\text { to non-SOEs }\end{array}$ \\
\hline & [1] & {$[2]$} & [3] & [4] \\
\hline \multirow[t]{2}{*}{ After $\times$ Treated } & -1.057 & $-1.241 *$ & 0.188 & -0.495 \\
\hline & {$[-0.35]$} & {$[-1.90]$} & {$[0.25]$} & {$[-1.63]$} \\
\hline \multirow[t]{2}{*}{ After } & $5.653 *$ & $1.444 * * *$ & 0.507 & $0.808 * * *$ \\
\hline & [1.86] & {$[2.58]$} & {$[0.72]$} & [3.30] \\
\hline \multirow[t]{2}{*}{ Treated } & $-5.076 * * *$ & $-1.665 * * *$ & -0.531 & $-0.682 * * *$ \\
\hline & {$[-2.94]$} & {$[-3.28]$} & {$[-1.19]$} & {$[-2.71]$} \\
\hline \multirow[t]{2}{*}{ ROA } & 25.283 & $-6.210 * *$ & -1.790 & $-2.418 * *$ \\
\hline & [1.59] & {$[-2.51]$} & {$[-0.46]$} & {$[-2.22]$} \\
\hline \multirow[t]{2}{*}{$\mathrm{OCF}$} & -7.340 & $0.928 * * *$ & $6.010 * * *$ & $0.586 * *$ \\
\hline & {$[-0.88]$} & {$[3.73]$} & {$[3.35]$} & [2.11] \\
\hline \multirow[t]{2}{*}{ Leverage } & $15.859 * * *$ & 1.444 & 1.840 & -0.035 \\
\hline & {$[2.70]$} & [1.40] & [1.17] & {$[-0.07]$} \\
\hline \multirow[t]{2}{*}{ Directors } & 0.211 & $1.063 * * *$ & $0.566 * * *$ & $0.562 * * *$ \\
\hline & [0.63] & [3.83] & [5.19] & {$[4.76]$} \\
\hline \multirow[t]{2}{*}{ Constant } & 0.203 & $-6.110 * * *$ & $-2.738 * *$ & $-2.859 * * *$ \\
\hline & {$[0.07]$} & {$[-2.83]$} & {$[-2.12]$} & {$[-3.21]$} \\
\hline $\mathrm{N}$ & 941 & 3827 & 731 & 3652 \\
\hline $\mathrm{R}^{2}$ & 0.031 & 0.034 & 0.051 & 0.045 \\
\hline Adjusted $\mathrm{R}^{2}$ & 0.023 & 0.033 & 0.041 & 0.043 \\
\hline Chow test & 10 & & & \\
\hline
\end{tabular}

Notes: The Table presents the CBRC credit control policy impact on single loan amount classed by bank ownership. Column 1 reports results for loans lent by SOBs to SOEs, Column 2 reports results for loans lent by SOBs to non-SOEs, Column 3 reports results for loans lent by non-SOBs to SOEs, and Column 4 reports results for loans lent by non-SOBs to non-SOEs. For variable definitions, see Table 2. Leverage is one year lagged. T-statistics are in parentheses and computed using the robust standard error clustered by firm. *, **, and *** indicate the significance levels at $10 \%, 5 \%$, and $1 \%$ respectively. 


\subsection{The impact of lending control policy on firm financing}

\subsubsection{Firm level bank loan issuance}

How does the credit control policy affect targeted firm's total borrowing from bank? Table 7 looks at the firm-year level observations, using changes in bank loans issuance as the dependent variable for Equation (1). I start with the change in long term bank loans7 issuance as the dependent variable. In Column 1, the estimated coefficient on the interaction between After and Treated is negative (-0.044) and significant at the $1 \%$ level, suggesting that firms targeted by the policy end up with a lower amount of long term bank loan issuance equal to $4.4 \%$ of their total asset size. Column 2 and 3 reproduce the regression in Column 1 for SOEs and non-SOEs separately. For non-SOEs sub-sample (Column 3), the key coefficient is -0.049 and highly statistically significant, meaning that the policy impact on the non-SOEs is significant, and economically larger than the full sample. For the SOEs sub-sample (Column 2), however, the interested coefficient becomes small and insignificant, suggesting that the policy barely affected SOEs. This result is consistent with the bank lending behavior we found in Table 6 .

I further apply total bank loans issuance as dependent variables in Column 4-6, examining the full sample, SOEs sample, and non-SOEs sample for each dependent variable. The results are similar with the case of long term bank loans issuance. For the full sample (Column 4), the interested coefficient is -0.114 and significant at the $10 \%$ level. For the SOE sample (Column 5), the interested coefficient is only -0.014 and statistically insignificant. For targeted non-SOEs (Column 6), total bank loan issuance dropped by $12.3 \%$ of their total assets relative to those not targeted nonSOEs. The Chow test statistics for SOEs and non-SOEs subgroup regressions are all significant at $1 \%$ level, further supporting the conclusion that banks treat SOEs and non-SOEs significantly differently after the credit policy.

I include several control variables related to loan borrowing. Among the control variables, I observe the expected signs consistent with previous studies. Specifically, the coefficient of firm size is only significantly positive for SOEs sample, indicating that banks are specifically interested in larger SOEs.

${ }^{7}$ Long term bank loan means loans with maturity longer than 1 year. 
Table 7: Effect of the credit control policy on firm borrowing from banks

\begin{tabular}{|c|c|c|c|c|c|c|}
\hline & \multicolumn{3}{|c|}{ Long term bank loan issuance } & \multicolumn{3}{|c|}{ Total bank loan issuance } \\
\hline & Full Sample & SOEs & Non-SOEs & Full Sample & SOEs & Non-SOEs \\
\hline & {$[1]$} & [2] & [3] & [4] & [5] & {$[6]$} \\
\hline \multirow[t]{2}{*}{ After $\times$ Treated } & $-0.044 * * *$ & 0.000 & $-0.049 * * *$ & $-0.114 *$ & -0.014 & $-0.123^{*}$ \\
\hline & {$[-2.67]$} & {$[0.05]$} & {$[-2.65]$} & {$[-1.88]$} & {$[-$} & {$[-1.83]$} \\
\hline \multirow[t]{2}{*}{ After } & -0.005 & 0.002 & -0.009 & -0.093 & -0.002 & -0.119 \\
\hline & {$[-0.28]$} & {$[0.30]$} & {$[-0.43]$} & {$[-1.16]$} & {$[-$} & {$[-1.24]$} \\
\hline \multirow[t]{2}{*}{ Treated } & 0.015 & -0.005 & 0.018 & 0.059 & 0.002 & 0.068 \\
\hline & {$[1.40]$} & {$[-0.87]$} & {$[1.44]$} & [1.37] & {$[0.24]$} & {$[1.35]$} \\
\hline \multirow[t]{2}{*}{ ROS } & -0.033 & 0.004 & -0.036 & -0.140 & -0.008 & -0.150 \\
\hline & {$[-1.15]$} & {$[0.45]$} & {$[-1.05]$} & {$[-1.20]$} & {$[-$} & {$[-1.08]$} \\
\hline \multirow[t]{2}{*}{ Size } & $0.015^{*}$ & $0.008 * *$ & $0.018 *$ & 0.058 & 0.028 & 0.067 \\
\hline & [1.77] & {$[3.02]$} & [1.67] & {$[1.50]$} & [3.16] & [1.43] \\
\hline \multirow[t]{2}{*}{ Leverage } & 0.035 & -0.008 & 0.040 & -0.009 & - & 0.005 \\
\hline & {$[0.85]$} & {$[-0.29]$} & {$[0.78]$} & {$[-0.06]$} & {$[-$} & {$[0.03]$} \\
\hline \multirow[t]{2}{*}{ Tobin's Q } & $0.018^{*}$ & 0.004 & $0.019 *$ & 0.075 & 0.018 & 0.079 \\
\hline & {$[1.73]$} & [1.21] & {$[1.73]$} & [1.48] & [2.15] & [1.48] \\
\hline \multirow[t]{2}{*}{ Cash } & -0.083 & 0.050 & -0.105 & $-0.532 *$ & -0.059 & -0.615 \\
\hline & {$[-1.12]$} & {$[1.06]$} & {$[-1.21]$} & {$[-1.66]$} & {$[-$} & {$[-1.63]$} \\
\hline \multirow[t]{2}{*}{ Director } & -0.000 & 0.000 & -0.001 & -0.002 & -0.001 & -0.003 \\
\hline & {$[-0.14]$} & {$[0.24]$} & {$[-0.29]$} & {$[-0.35]$} & {$[-$} & {$[-0.44]$} \\
\hline \multirow[t]{2}{*}{$\mathrm{OCF}$} & $0.936 *$ & -0.044 & $0.980 *$ & 3.279 & -0.333 & 3.444 \\
\hline & {$[1.84]$} & {$[-0.51]$} & {$[1.87]$} & [1.45] & {$[-$} & [1.48] \\
\hline \multirow[t]{2}{*}{ Constant } & $-0.392 * *$ & - & $-0.455^{*}$ & -1.392 & - & -1.574 \\
\hline & {$[-2.01]$} & {$[-3.25]$} & {$[-1.86]$} & {$[-1.62]$} & {$[-$} & {$[-1.53]$} \\
\hline $\mathrm{N}$ & 5544 & 1040 & 4504 & 5544 & 1040 & 4504 \\
\hline $\mathrm{R}^{2}$ & 0.311 & 0.034 & 0.328 & 0.304 & 0.082 & 0.322 \\
\hline Adjusted $\mathrm{R}^{2}$ & 0.309 & 0.025 & 0.327 & 0.303 & 0.073 & 0.320 \\
\hline Chow test & \multicolumn{3}{|c|}{$59.88 * * *$} & \multicolumn{3}{|c|}{$71.02 * * *$} \\
\hline
\end{tabular}

Notes: The Table presents the CBRC credit control policy impact on firm borrowing from banks. The dependent variable for Column 1-3 is change in firm's outstanding long term bank borrowing to start-of-period assets. The dependent variable for Column 4-6 is change in change in firm's outstanding total bank borrowing to start-of-period assets. Column 1 and 4 report results for all firms, Column 2 and 5 report results for SOEs, and Column 3 and 6 report results for non-SOEs. For variable definitions, see Table 2. Leverage and Tobin's Q are one year lagged. T-statistics are in parentheses and computed using the robust standard error clustered by firm. *, **, and *** indicate the significance levels at $10 \%, 5 \%$, and $1 \%$ respectively.

\subsubsection{Other external funding: bond issuance, trade credit, and equity issuance}

How does the policy affect external funding other than bank borrowing? Assuming a well-developed capital markets with low cost of shifting between funding sources, affected firms would seek alternative external funding, such as bond issuance, trade credit, and equity issuance, to cushion the credit contraction shock. However, in 
China, where bank financing plays the major role and funding shifting cost is high, firms usually find it difficult to fully substitute credit contraction with bond, trade credit, or equity. In fact, according to Yi, banks are the major investors of bonds in China. By 2018, 51.5\% of bonds in China are held by commercial banks (Yi 2020). When banks decided to lend less to a firm, they naturally reduce investment to the firms' bond too. Moreover, the CBRC policy informs potential shareholders and lenders that the targeted firms are facing stricter bank credit rationing. Such expectation would significantly discourage investors and upstream and downstream firms from funding affected firms. In this case, other external funding would also decrease, amplifying the credit supply shock.

Table 8 presents evidence consistent with these predictions about alternative external funding. Panel A shows the OLS estimates when using bond issuance, trade credit, and equity issuance as dependent variables for Equation (1). The results suggest that for the full sample, bond issuance and trade credit of targeted firms decreased by $2.2 \%$ (Column 1) and 6\% (Column 4 ) of their total assets relative to non-targeted firms, both significant at the $1 \%$ level. For non-SOEs, bond issuance and trade credit dropped by $2.1 \%$ and $5.7 \%$ of their assets. For SOEs, bond issuance does not change significantly, while their borrowing from upstream and downstream firms dropped by $8.4 \%$. Equity funding does not change significantly. ${ }^{8}$ Since the alternative funding may not be only affected by the credit control policy, Following (Banerjee and Duflo, 2014); (Berg, 2018), I use AfterxTreated as IV to measure the local impact of an exogenous change in bank credit supply on bond issuance, trade financing, and equity issuance. Panel B of Table 8 reports the IV estimates. Here, I regress long term bank loan issuance on the IV (After $\times$ Treated) in the first step (Equation 2). The results show that, for the full sample, a 1 CNY decrease in long term bank loan supply leads to a $0.453 \mathrm{CNY}$ decrease in bond issuance and 1.275 CNY decrease in trade credit. All the estimates are statistically significant. Interestingly, when applying the IV method, the negative impact on bond issuance and trade financing is only significant for non-SOEs. Again, results show that alternative external funding of SOEs are not affected by the policy.

Columns 7-9 examine the impact of the policy shock on equity finance. The interested estimates in both Panel A and Panel B becomes insignificant, indicating that the lending control policy does not affect equity finance of targeted firms.

8 This finding is in line with the development of China's capital market during the year of 2012 2017. Up to date, firm equity funding is still under strict control of the Chinese Security Regulatory Committee. The firm can hardly shift freely to equity funding after the credit control policy, so the policy impact on equity funding is minimal. 
Table 8: Effect of the credit control policy on bond issuance, trade credit, and equity finance

\begin{tabular}{|c|c|c|c|c|c|c|c|c|c|}
\hline & \multicolumn{3}{|c|}{ Bond issuance } & \multicolumn{3}{|c|}{ Trade credit } & \multicolumn{3}{|c|}{ Equity finance } \\
\hline & Full Sample & SOEs & Non-SOEs & Full Sample & SOEs & Non-SOEs & Full Sample & SOEs & Non-SOEs \\
\hline & [1] & [2] & [3] & [4] & [5] & [6] & [7] & [8] & [9] \\
\hline \multicolumn{10}{|c|}{ Panel A. OLS estimates } \\
\hline \multirow[t]{2}{*}{ After $\times$ Treated } & $-0.022 * * *$ & -0.021 & $-0.021 * * *$ & $-0.060 * * *$ & $-0.084 * *$ & $-0.057 * * *$ & 0.041 & -0.013 & 0.056 \\
\hline & {$[-3.24]$} & {$[-1.22]$} & {$[-3.13]$} & {$[-3.08]$} & {$[-2.13]$} & {$[-2.65]$} & {$[0.92]$} & {$[-1.19]$} & {$[1.00]$} \\
\hline \multirow[t]{2}{*}{ After } & 0.004 & -0.011 & 0.007 & 0.062 & 0.040 & 0.066 & -0.038 & $0.025 * *$ & -0.045 \\
\hline & [0.79] & {$[-1.01]$} & [1.37] & {$[1.62]$} & [1.40] & {$[1.53]$} & {$[-0.71]$} & {$[2.11]$} & {$[-0.75]$} \\
\hline \multirow[t]{2}{*}{ Treated } & $0.012 *$ & 0.036 & $0.008 * *$ & $0.037 * * *$ & $0.052 * *$ & $0.034 * * *$ & $0.013^{*}$ & $0.013 *$ & 0.016 \\
\hline & [1.87] & {$[1.00]$} & {$[2.52]$} & {$[3.04]$} & {$[2.18]$} & {$[2.71]$} & [1.73] & {$[1.79]$} & [1.37] \\
\hline Control & Yes & Yes & Yes & Yes & Yes & Yes & Yes & Yes & Yes \\
\hline $\mathrm{N}$ & 4688 & 871 & 3817 & 5544 & 1040 & 4504 & 5542 & 1040 & 4502 \\
\hline $\mathrm{R}^{2}$ & 0.065 & 0.022 & 0.103 & 0.212 & 0.334 & 0.209 & 0.080 & 0.151 & 0.087 \\
\hline Adjusted $\mathrm{R}^{2}$ & 0.063 & 0.009 & 0.100 & 0.211 & 0.329 & 0.208 & 0.079 & 0.144 & 0.085 \\
\hline Chow test & \multicolumn{3}{|c|}{$1.97 * *$} & \multicolumn{3}{|c|}{$3.05 * * *$} & \multicolumn{3}{|c|}{$4.68 * * *$} \\
\hline \multicolumn{10}{|c|}{ Panel B. IV estimates } \\
\hline \multirow{2}{*}{$\begin{array}{l}\text { First stage: using long } \\
\text { term loan }\end{array}$} & $-0.051 *$ & -0.004 & $-0.063 *$ & $-0.052 * *$ & -0.002 & $-0.064 * *$ & $-0.052 * *$ & -0.002 & $-0.064 * *$ \\
\hline & {$[-1.95]$} & {$[-0.49]$} & {$[-1.93]$} & {$[-2.37]$} & {$[-0.24]$} & {$[-2.37]$} & {$[-2.37]$} & {$[-0.24]$} & {$[-2.37]$} \\
\hline \multirow{2}{*}{ IV: using long term loan } & $0.453 *$ & 6.26 & $0.339 *$ & $1.275^{* *}$ & 30.43 & $1.037 * *$ & 0.265 & 4.37 & 0.146 \\
\hline & [1.67] & {$[0.46]$} & {$[1.65]$} & {$[2.47]$} & {$[0.24]$} & [2.21] & {$[0.18]$} & {$[0.23]$} & {$[0.10]$} \\
\hline $\mathrm{N}$ & 4688 & 871 & 3817 & 5544 & 1040 & 4504 & 5544 & 1040 & 4504 \\
\hline
\end{tabular}

The Table presents the CBRC credit control policy impact on firm external funding. Panel A reports the OLS regression following Equation (1). For Column 1-3, the dependent variable is change in firm's payable bond to start-of-period assets, and the control variables include ROS, Size, one year lagged leverage, one year lagged Tobin's Q, one year lagged Cash, Director, Tangibility, and OCF. For Column 4-6, the dependent variable is change in firm's trade credit, and the control variables include Size, one year lagged Leverage, one year lagged Tobin's Q, Tangibility, and OCF. For Column 7-9, the dependent variable is change in firm's equity issuance, and the control variables include ROS Size one year lagged Leverage, one year lagged Tobin's Q, one year lagged Cash, and Growth. Column 1, 4 and 7 report results for all firms; Column 2, 5 and 8 report results for SOEs; Column 3, 6 and 9 report results for non-SOEs. Panel B reports the IV estimates following Equation (2) and (3). For variable definitions, see Table 2 . T-statistics are in parentheses and computed using the robust standard error clustered by firm. *, **, and *** indicate the significance levels at $10 \%, 5 \%$, and $1 \%$ respectively. 


\subsection{The impact of the lending control policy on firm cash holdings}

How does the credit supply drop transmit to the asset side, especially cash holdings? Precautionary savings theory assumes that firms use cash holdings as a buffer against cash flow shocks. In this case, firms would have lower cash holdings due to the negative cash flow shock introduced by the decreased credit supply. However, the affected firms may also increase cash holding as their internal funding sources in response to the drop of external finance. Therefore, it is hard to predict whether cash holdings would increase or decrease after the credit control policy.

Table 9 sheds light on the question. Following common practice in literature, cash holding is defined as the ratio of the change in the total of cash and marketable assets to start-of-period assets. Column 1 examines the full sample. The coefficient on the interaction variable After $\times$ Treated is -0.061 and statistically significant at $10 \%$ level, suggesting that targeted firms decreased cash holdings by $6.1 \%$ of their total assets.

Panel B of Table 9 presents the IV regression results for change of cash holdings. The result shows that a $1 \mathrm{CNY}$ decrease in bank long term loan issuance triggers $1.35 \mathrm{CNY}$ decrease in firm cash holdings. The result confirms the hypothesis that firms cushion the funding shortfall with internal funding by exhausting cash holdings. However, the change of cash holding $(1.353 \mathrm{CNY})$ is far from completely substituting the external funding decrease, which is about a decrease of $2.73 \mathrm{CNY}$ (1 CNY decrease in total bank loans, $0.45 \mathrm{CNY}$ decrease in bond issuance, and 1.28 decrease in trade credit). 
Table 9: Effect of the credit control policy on cash holdings

\begin{tabular}{|c|c|c|c|}
\hline & \multicolumn{3}{|c|}{ Cash holdings } \\
\hline & Full Sample & SOEs & Non-SOEs \\
\hline & [1] & [2] & [3] \\
\hline \multicolumn{4}{|c|}{ Panel A. OLS estimates } \\
\hline \multirow[t]{2}{*}{ After $\times$ Treated } & $-0.061 *$ & -0.048 & $-0.055^{*}$ \\
\hline & {$[-1.90]$} & {$[-0.58]$} & {$[-1.75]$} \\
\hline \multirow[t]{2}{*}{ After } & -0.014 & -0.080 & -0.005 \\
\hline & {$[-0.37]$} & {$[-1.19]$} & {$[-0.11]$} \\
\hline \multirow[t]{2}{*}{ Treated } & 0.015 & 0.041 & 0.007 \\
\hline & {$[0.67]$} & {$[0.43]$} & {$[0.44]$} \\
\hline \multirow[t]{2}{*}{$\mathrm{OCF}$} & 0.818 & -0.306 & 0.844 \\
\hline & {$[1.31]$} & {$[-0.56]$} & {$[1.33]$} \\
\hline \multirow[t]{2}{*}{ Size } & $0.063 * *$ & 0.076 & $0.061 * *$ \\
\hline & {$[2.35]$} & [1.53] & [1.99] \\
\hline \multirow[t]{2}{*}{ Tobin's Q } & $0.055^{*}$ & $0.063 * *$ & $0.055^{*}$ \\
\hline & [1.90] & {$[2.06]$} & {$[1.84]$} \\
\hline \multirow[t]{2}{*}{ Leverage } & 0.118 & -0.004 & 0.146 \\
\hline & [1.27] & {$[-0.05]$} & [1.36] \\
\hline \multirow[t]{2}{*}{ Age } & $0.029^{*}$ & 0.081 & 0.022 \\
\hline & {$[1.96]$} & {$[1.51]$} & {$[1.48]$} \\
\hline \multirow[t]{2}{*}{ Constant } & $-1.563 * * *$ & -1.933 & $-1.512 * *$ \\
\hline & {$[-2.61]$} & {$[-1.52]$} & {$[-2.26]$} \\
\hline $\mathrm{N}$ & 4666 & 864 & 3802 \\
\hline $\mathrm{R}^{2}$ & 0.178 & 0.016 & 0.266 \\
\hline Adjusted $\mathrm{R}^{2}$ & 0.177 & 0.007 & 0.265 \\
\hline Chow test & \multicolumn{3}{|c|}{$3.15 * * *$} \\
\hline \multicolumn{4}{|c|}{ Panel B. IV estimates } \\
\hline \multirow[t]{2}{*}{ First stage: using long term loan } & $-0.058 * *$ & -0.005 & $-0.071 * *$ \\
\hline & {$[-2.13]$} & {$[-0.59]$} & {$[-2.11]$} \\
\hline \multirow{2}{*}{ IV: using long term loan } & $1.353^{* *}$ & 13.27 & $1.046 * * *$ \\
\hline & {$[2.31]$} & {$[0.43]$} & {$[2.71]$} \\
\hline $\mathrm{N}$ & 4666 & 864 & 3802 \\
\hline
\end{tabular}

Notes: The Table presents the CBRC credit control policy impact on firm cash holdings. Panel A reports the OLS regression following Equation (1). The dependent variable is the ratio of the change in the total of cash and marketable assets to start-of-period assets. Column 1 reports results for all firms, Column 2 reports results for SOEs, and Column 3 reports results for non-SOEs. Panel B reports the IV estimates following Equation (2) and (3). For variable definitions, see Table 2. Leverage and Tobin's $\mathrm{Q}$ are one year lagged. T-statistics are in parentheses and computed using the robust standard error clustered by firm. $*, * *$, and $* * *$ indicate the significance levels at $10 \%, 5 \%$, and $1 \%$ respectively. 
When splitting the sample by firm ownership, results again shows that only nonSOEs fell victim of bank credit rationing. Column 3 of Panel A shows that targeted non-SOEs reduce cash holdings by $5.5 \%$ of their total assets compared with counterparts, while targeted SOEs does not adjust their cash holdings significantly. The IV result (Column 3 of Panel B) shows that 1 CNY decrease in bank long term loan issuance triggers $1.05 \mathrm{CNY}$ decrease in firm cash holdings for affected nonSOEs.

\subsection{The impact of lending control policy on firm investment}

So far, I have examined how CBRC lending control policy affected banks' lending decision and firm funding. Evidence shows that bank borrowing dropped significantly together with bond issuance and trade credit for the targeted firms, and that firms cushions the funding shortfalls with more use of internal finance. It also shows that only non-SOEs are affected by the credit contraction shock, while SOEs are barely affected in all aspects of financing.

In this section, I focus on the real effect of the lending control policy, or how the policy changed investment of affected firms.

\subsubsection{Net investment}

Table 10 looks at the policy impact on firm investment. Here, the dependent variable for Equation (1) is defined as the ratio of (cash paid to purchase fixed assets, acquire intangible assets and other long-term assets + cash paid to acquire subsidiaries and other business units) to start-of-period assets. 
Table 10: Effect of the credit control policy on firm investment

\begin{tabular}{|c|c|c|c|}
\hline & \multicolumn{3}{|c|}{ Investment } \\
\hline & Full Sample & SOEs & Non-SOEs \\
\hline & [1] & [2] & [3] \\
\hline \multicolumn{4}{|c|}{ Panel A. OLS estimates } \\
\hline \multirow[t]{2}{*}{ After $\times$ Treated } & $-0.052 * *$ & -0.009 & $-0.057 * *$ \\
\hline & {$[-2.35]$} & {$[-0.63]$} & {$[-2.17]$} \\
\hline \multirow{2}{*}{ After } & -0.023 & -0.005 & -0.029 \\
\hline & {$[-0.89]$} & {$[-0.67]$} & {$[-0.97]$} \\
\hline \multirow[t]{2}{*}{ Treated } & 0.018 & 0.006 & 0.020 \\
\hline & [1.48] & [1.16] & [1.36] \\
\hline \multirow[t]{2}{*}{ Size } & $0.036^{* *}$ & $0.009 * * *$ & $0.043 * *$ \\
\hline & [2.27] & [2.91] & [2.27] \\
\hline \multirow{2}{*}{ Leverage } & 0.109 & 0.003 & 0.118 \\
\hline & [1.55] & {$[0.19]$} & [1.38] \\
\hline \multirow{2}{*}{ Cash } & $-0.196^{*}$ & 0.011 & $-0.224 *$ \\
\hline & {$[-1.81]$} & {$[0.17]$} & {$[-1.77]$} \\
\hline \multirow[t]{2}{*}{ Tobin's Q } & $0.046^{* *}$ & $0.011^{* * *} *$ & $0.048^{* *}$ \\
\hline & [2.11] & [2.68] & [2.10] \\
\hline \multirow[t]{2}{*}{$\mathrm{OCF}$} & $1.004^{*}$ & 0.079 & $1.046^{*}$ \\
\hline & {$[1.83]$} & {$[0.80]$} & {$[1.85]$} \\
\hline \multirow[t]{2}{*}{ Age } & $-0.032 * * *$ & -0.003 & $-0.034 * * *$ \\
\hline & {$[-3.27]$} & {$[-0.60]$} & {$[-3.11]$} \\
\hline \multirow{2}{*}{ Constant } & $-0.747 * *$ & $-0.157 * *$ & $-0.895 * *$ \\
\hline & {$[-2.10]$} & {$[-2.05]$} & {$[-2.15]$} \\
\hline $\mathrm{N}$ & 5544 & 1040 & 4504 \\
\hline $\mathrm{R}^{2}$ & 0.280 & 0.032 & 0.292 \\
\hline Adjusted $\mathrm{R}^{2}$ & 0.278 & 0.023 & 0.291 \\
\hline Chow test & \multicolumn{3}{|c|}{$8.82 * * *$} \\
\hline \multicolumn{4}{|c|}{ Panel B. IV estimates } \\
\hline \multirow[t]{2}{*}{ First stage: using long } & $-0.052 * *$ & -0.002 & $-0.064 * *$ \\
\hline & {$[-2.37]$} & {$[-0.24]$} & {$[-2.37]$} \\
\hline \multirow[t]{2}{*}{ IV: using long term } & $1.252 * * *$ & 3.517 & $1.209 * * *$ \\
\hline & [3.04] & {$[0.26]$} & [2.99] \\
\hline $\mathrm{N}$ & 5544 & 1040 & 4504 \\
\hline
\end{tabular}

Notes: The Table presents the CBRC credit control policy impact on firm investment. Panel A reports the OLS regression following Equation (1). The dependent variable is The ratio of (cash paid to purchase fixed assets, acquire intangible assets and other long-term assets + cash paid to acquire subsidiaries and other business units) to start-of-period assets. Column 1 reports results for all firms, Column 2 reports results for SOEs, and Column 3 reports results for non-SOEs. Leverage, Cash and Tobin's Q are one year lagged. Panel B reports the IV estimates following Equation (2) and (3). For variable definitions, see Table 2. T-statistics are in parentheses and computed using the robust standard error clustered by firm. *, **, and *** indicate the significance levels at $10 \%, 5 \%$, and $1 \%$ respectively. 
Column 1 of Table 10 shows that investment of targeted firms drop by 5.2\% of total asset size relative to non-targeted firms, and the decrease is statistically significant at the 5\% level. When splitting the sample by firm ownership, results further support the narrative that the CBRC lending control policy affects non-SOEs only. While Column 3 shows that non-SOEs cut their investment by 5.7\% of total asset (significant at the 5\% level), Column 2 shows that the corresponding coefficient for SOEs is small (-0.9\%) and statistically insignificant.

Panel B of Table 10 presents the IV estimated for the policy impact on firm investment. Result shows that a decrease of $1 \mathrm{CNY}$ in long term bank loan issuance triggers 1.25 CNY drop in firm investment. The real effect of the CBRC credit control policy is proven both economically and statistically significant. The IV method also confirms the narrative that the policy affects non-SOEs more remarkably than SOEs. Results show that for targeted non-SOEs, 1 CNY decrease of long term bank loan issuance leads to 1.21 CNY firm investment decrease. For SOEs, the local impact of credit contraction on firm investment is insignificant.

For robustness check, I try three alternative measurements for firm investment in Table 11. Definitions of Investment_2, Investment_3 and Investment_4 can be found in Table 2. Both OLS and IV estimates in Table 11 shows that the estimation of the policy impact on firm investment is robust, regardless of the investment measurements. 
Table 11: Effect of the credit control policy on firm investment: alternative investment measurements

\begin{tabular}{|c|c|c|c|c|c|c|c|c|c|}
\hline & \multicolumn{3}{|c|}{ Investment_2 } & \multicolumn{3}{|c|}{ Investment_3 } & \multicolumn{3}{|c|}{ Investment_4 } \\
\hline & Full & SOEs & Non-SOEs & Full & SOEs & Non-SOEs & Full & SOEs & Non-SOEs \\
\hline & [1] & [2] & [3] & [4] & [5] & {$[6]$} & [7] & [8] & [9] \\
\hline \multicolumn{10}{|c|}{ Panel A. OLS estimates } \\
\hline \multirow[t]{2}{*}{ After $\times$ Treated } & $-0.035 * *$ & -0.012 & $-0.038 * *$ & $-0.048 * *$ & -0.005 & $-0.053 * *$ & $-0.046 * *$ & -0.007 & $-0.050 * *$ \\
\hline & {$[-2.16]$} & {$[-1.60]$} & {$[-2.06]$} & {$[-2.30]$} & {$[-0.37]$} & {$[-2.14]$} & {$[-2.55]$} & {$[-0.51]$} & {$[-2.32]$} \\
\hline \multirow[t]{2}{*}{ After } & -0.039 & -0.010 & -0.047 & -0.023 & -0.010 & -0.027 & 0.002 & -0.009 & 0.002 \\
\hline & {$[-1.51]$} & {$[-1.48]$} & {$[-1.56]$} & {$[-0.96]$} & {$[-1.33]$} & {$[-1.01]$} & {$[0.18]$} & {$[-1.23]$} & {$[0.12]$} \\
\hline \multirow[t]{2}{*}{ Treated } & 0.019 & 0.006 & 0.021 & 0.014 & 0.009 & 0.014 & 0.005 & 0.001 & 0.005 \\
\hline & [1.64] & [1.38] & {$[1.55]$} & [1.30] & {$[1.62]$} & [1.08] & {$[0.66]$} & {$[0.21]$} & {$[0.55]$} \\
\hline Control & Yes & Yes & Yes & Yes & Yes & Yes & Yes & Yes & Yes \\
\hline $\mathrm{N}$ & 5544 & 1040 & 4504 & 5544 & 1040 & 4504 & 5544 & 1040 & 4504 \\
\hline $\mathrm{R}^{2}$ & 0.320 & 0.051 & 0.335 & 0.266 & 0.034 & 0.278 & 0.185 & 0.042 & 0.195 \\
\hline Adjusted $\mathrm{R}^{2}$ & 0.319 & 0.043 & 0.334 & 0.265 & 0.026 & 0.277 & 0.184 & 0.033 & 0.194 \\
\hline Chow test & \multicolumn{3}{|c|}{$9.92 * *$} & \multicolumn{3}{|c|}{$7.33 * * *$} & \multicolumn{3}{|c|}{$5.32 * * *$} \\
\hline \multicolumn{10}{|c|}{ Panel B. IV estimates } \\
\hline \multirow{2}{*}{$\begin{array}{l}\text { First stage: using } \\
\text { long term loan }\end{array}$} & $-0.052 * *$ & -0.002 & $-0.064 * *$ & $-0.052 * *$ & -0.002 & $-0.064 * *$ & $-0.052 * *$ & -0.002 & $-0.064 * *$ \\
\hline & {$[-2.37]$} & {$[-0.24]$} & {$[-2.37]$} & {$[-2.37]$} & {$[-0.24]$} & {$[-2.37]$} & {$[-2.37]$} & {$[-0.24]$} & {$[-2.37]$} \\
\hline \multirow{2}{*}{$\begin{array}{l}\text { IV: using long } \\
\text { term loan }\end{array}$} & $0.870 *$ & 5.310 & $0.849 * * *$ & $1.166^{* *}$ & 1.874 & $1.129 * * *$ & $1.030 * *$ & 3.874 & $0.967 * *$ \\
\hline & {$[3.92]$} & {$[0.26]$} & {$[3.86]$} & {$[2.87]$} & {$[0.24]$} & {$[2.83]$} & {$[2.47]$} & {$[0.26]$} & {$[2.40]$} \\
\hline $\mathrm{N}$ & 5544 & 1040 & 4504 & 5544 & 1040 & 4504 & 5544 & 1040 & 4504 \\
\hline
\end{tabular}

The Table presents the robustness test for CBRC credit control policy impact on firm investment, testing alternative measurements of investment. For Column 1-3, the dependent variable is Investment_2; for Column 4-6, the dependent variable is Investment_3; for Column 7-9, the dependent variable is Investment_4. Panel A reports the OLS regression following Equation (1). Column 1, 4 and 7 report results for all firms; Column 2, 5 and 8 report results for SOEs; Column 3, 6 and 9 report results for non-SOEs. Panel B reports the IV estimates following Equation (2) and (3). Leverage, Cash and Tobin's $\mathrm{Q}$ are one year lagged. Panel B reports the IV estimates following Equation (2) and (3). For variable definitions, see Table 2. T-statistics are in parentheses and computed using the robust standard error clustered by firm. *,**, and *** indicate the significance levels at $10 \%, 5 \%$, and $1 \%$ respectively. 


\subsubsection{Investment inefficiency}

If the firms invest less due to the CBRC policy, do they invest more efficiently? The answer is unfortunately no. Following (Deng et al., 2020); (Richardson, 2006), I use the following model to estimate the inefficient investment:

Investment $_{\mathrm{it}}=\alpha_{0}+\beta_{1}$ Investment $_{\mathrm{i}-1}+\beta_{2}$ Leverage $_{\mathrm{it}-1}+\beta_{3}$ Cash $_{\mathrm{it}-1}+\beta_{4}$ Age $_{\mathrm{it}-1}$ $\beta_{5}$ Size $_{\mathrm{it}-1}+\beta_{6}$ return $_{\mathrm{it}-1}+\beta_{7} M B_{\mathrm{it}-1}+\alpha_{i}+\alpha_{t}+\varepsilon_{\mathrm{it}}$

where Leverage is firm book leverage, Cash is cash holdings (marketable assets are not included here), Age is firm age, Size is log of total assets, return is the yearly stock return (including reinvestment return of dividends), MB is the market to book ratio. The regression controls firm fixed effect and time fixed effect. The absolute value of the residual from Equation (4) is defined as the abnormal or inefficient investment.

I use the estimated inefficient investment as the dependent variable for Equation (1). Table 12 presents the result. Column 1 shows that inefficient investment of targeted firms increased by $3.2 \%$ of their total balance sheet size, and the increase is statistically significant at the 5\% level. Column 2 and Column 3 looks at SOEs and non-SOEs separately, and it shows that only non-SOEs invest less efficiently. Panel B of Table 12 presents the IV estimates for inefficient investment. When using long term bank loan as the IV, the result shows that a $1 \mathrm{CNY}$ long term loan decrease leads to a $0.733 \mathrm{CNY}$ value of inefficient investment increase for non-SOEs. 
Table 12: Effect of the credit control policy on inefficient investment

\begin{tabular}{|c|c|c|c|}
\hline & \multicolumn{3}{|c|}{ Inefficient investment } \\
\hline & Full Sample & SOEs & Non-SOEs \\
\hline & [1] & [2] & [3] \\
\hline \multicolumn{4}{|c|}{ Panel A. OLS estimates } \\
\hline \multirow[t]{2}{*}{ After $\times$ Treated } & $0.032 * *$ & -0.027 & $0.047 * * *$ \\
\hline & [2.25] & {$[-0.81]$} & {$[3.00]$} \\
\hline \multirow[t]{2}{*}{ After } & $-0.028 * * *$ & 0.005 & $-0.035 * * *$ \\
\hline & {$[-2.92]$} & {$[0.22]$} & {$[-3.39]$} \\
\hline \multirow[t]{2}{*}{ Treated } & $-0.102 * * *$ & $-0.075 * * *$ & $-0.108 * * *$ \\
\hline & {$[-10.83]$} & {$[-3.43]$} & {$[-10.48]$} \\
\hline \multirow[t]{2}{*}{ Board } & 0.003 & $0.016^{* * * *}$ & -0.002 \\
\hline & [1.23] & [3.72] & {$[-0.98]$} \\
\hline \multirow[t]{2}{*}{ Shareholder1 } & -0.000 & $0.001 * * *$ & $-0.001 *$ \\
\hline & {$[-0.43]$} & [2.77] & {$[-1.93]$} \\
\hline \multirow[t]{2}{*}{ Constant } & $0.366 * * *$ & $0.173 * * *$ & $0.428 * * *$ \\
\hline & [16.25] & [3.92] & [16.14] \\
\hline $\mathrm{N}$ & 5541 & 1039 & 4502 \\
\hline $\mathrm{R}^{2}$ & 0.026 & 0.043 & 0.028 \\
\hline Adjusted $\mathrm{R}^{2}$ & 0.025 & 0.038 & 0.027 \\
\hline Chow test & & $92 * * *$ & \\
\hline \multicolumn{4}{|c|}{ IV estimates } \\
\hline \multirow{2}{*}{$\begin{array}{c}\text { First stage: } \\
\text { using long term loan }\end{array}$} & $-0.052 * *$ & -0.002 & $-0.064 * *$ \\
\hline & {$[-2.37]$} & {$[-0.24]$} & {$[-2.37]$} \\
\hline \multirow[t]{2}{*}{ IV: using long term } & -0.617 & 14,77 & $-0.733^{*}$ \\
\hline & {$[-1.52]$} & {$[0.22]$} & {$[-1.74]$} \\
\hline $\mathrm{N}$ & 5541 & 1039 & 4502 \\
\hline
\end{tabular}

Notes: The Table presents the CBRC credit control policy impact on firm inefficient investment. Panel A reports the OLS regression following Equation (1). The dependent variable is inefficient investment, whose definition can be found in Section 5.4.2. Column 1 reports results for all firms, Column 2 reports results for SOEs, and Column 3 reports results for non-SOEs. Panel B reports the IV estimates following Equation (2) and (3). For variable definitions, see Table 2. T-statistics are in parentheses and computed using the robust standard error clustered by firm. *,**, and *** indicate the significance levels at $10 \%, 5 \%$, and $1 \%$ respectively.

\subsection{Alternative Interpretations}

Did banks restrict loans to targeted firms due to higher taxation rather than credit control policy?Apparently, the credit control policy is not the only tool that government used to contain the growth of polluting industries. Apart from the credit control policy, government also imposed higher taxation on polluting firms to discourage their operation. Therefore, I need to exclude the competing hypothesis that banks decreased their lending to targeted firms because these firms faced higher taxation and expected lower profitability.

To exclude this concern, I include business taxation as a control variable in Equation 
1. Column 1 and 4 of Table 13 show that taxation costs cannot explain the change in bank loans decline. After I included taxation in Equation 1, the coefficient of interaction After $\times$ Treated are still significantly negative, for both dependent variables of long term bank loans issuance and total bank loans issuance.

Did banks restrict loans to targeted firms because they have higher firm risks?Another identification concern arises from the possibility that banks may worry about higher firm risks due to future anti-pollution regulation uncertainties. For example, we frequently observe cases that local government suspends business licenses of polluting firms in recent years.

To exclude this concern, I use the standard deviation of firms' ROA to measure the firms risk and control the variable in Equation 1. For each firm, I calculate the standard deviations of ROA for the periods of 2011-2014 and 2014-2017. Columns 2 and 5 of Table 13 show that firm risk cannot explain the change in bank loans decline. After I included firm risk in Equation 1, the coefficient of interaction After $\times$ Treated is still significantly negative, for both dependent variables of long term bank loans issuance and total bank loans issuance. Column 3 and 6 include both taxation and firm risk as control variables, and the result remains robust.

Table 13: Robustness tests: Taxation costs and firm risk cannot explain the bank loan decline

\begin{tabular}{|l|c|c|c|c|c|c|}
\hline & \multicolumn{3}{|c|}{ Long term bank loan issuance } & \multicolumn{3}{c|}{ Total bank loan issuance } \\
\cline { 2 - 7 } & Full Sample & SOEs & Non-SOEs & Full Sample & SOEs & Non-SOEs \\
\cline { 2 - 7 } & {$[1]$} & {$[2]$} & {$[3]$} & {$[4]$} & {$[5]$} & {$[6]$} \\
\hline After×Treated & $-0.035^{* *}$ & $-0.045^{* * *}$ & $-0.036^{* *}$ & $-0.080^{*}$ & $-0.121^{* *}$ & $-0.088^{*}$ \\
\hline & {$[-2.47]$} & {$[-2.73]$} & {$[-2.57]$} & {$[-1.70]$} & {$[-1.98]$} & {$[-1.87]$} \\
\hline After & -0.005 & 0.004 & 0.004 & -0.095 & -0.048 & -0.049 \\
\hline & {$[-0.30]$} & {$[0.33]$} & {$[0.30]$} & {$[-1.16]$} & {$[-0.98]$} & {$[-0.98]$} \\
\hline Treated & 0.007 & 0.013 & 0.006 & 0.031 & 0.053 & 0.026 \\
\hline & {$[0.92]$} & {$[1.32]$} & {$[0.78]$} & {$[1.06]$} & {$[1.26]$} & {$[0.87]$} \\
\hline Tax & $-0.027^{* *}$ & & $-0.028^{* *}$ & $-0.104^{*}$ & & $-0.107 *$ \\
\hline & {$[-2.05]$} & & {$[-2.08]$} & {$[-1.77]$} & & {$[-1.81]$} \\
\hline Risk & & 0.227 & 0.222 & & 1.159 & 1.145 \\
\hline Control & & {$[1.44]$} & {$[1.42]$} & & {$[1.41]$} & {$[1.41]$} \\
\hline $\mathrm{N}$ & Yes & Yes & Yes & Yes & Yes & Yes \\
\hline $\mathrm{R}^{2}$ & 5533 & 5544 & 5533 & 5533 & 5544 & 5533 \\
\hline Adjusted $\mathrm{R}^{2}$ & 0.317 & 0.318 & 0.324 & 0.312 & 0.319 & 0.326 \\
\hline
\end{tabular}

Notes: The Table presents the robustness test considering firm tax burden and business risk. Panel A reports the OLS regression following Equation (1). The dependent variable for Column 1-3 is change in firm's outstanding long term bank borrowing to start-of-period assets. The dependent variable for Column 4-6 is change in change in firm's outstanding total bank borrowing to start-ofperiod assets. Column 1 and 4 report results for all firms, Column 2 and 5 report results for SOEs, and Column 3 and 6 report results for non-SOEs. For variable definitions, see Table 2. Leverage and Tobin's Q are one year lagged. T-statistics are in parentheses and computed using the robust standard error clustered by firm. *, **, and $* * *$ indicate the significance levels at $10 \%, 5 \%$, and $1 \%$ respectively. 


\subsection{Placebo test}

To further justify the identification of the 2014 policy shock on bank decisions and firm behavior, I apply the same empirical strategy in section 5.1 to 5.4 to the observations from the period of 2010-2015, assuming the credit control policy happened in 2012. I choose this period of time specifically to avoid the impact of 4 trillion RMB stimulus in 2009. Table 14 presents the result of the placebo test. It shows that the interested coefficients of the interaction AfterxTreated are no longer significant. The conclusions from the 2014 policy shock are further supported.

Table 14: Placebo test (covering 2010-2015, assuming shock occurred in 2012)

\begin{tabular}{|c|c|}
\hline Dependent variables & Coefficient of After×Treated \\
\hline$[1]$ & {$[2]$} \\
\hline Long term bank loan & 0.003 \\
\hline & {$[0.19]$} \\
\hline Toal bank loan issuance & -0.013 \\
\hline & {$[-0.91]$} \\
\hline Bond issuance & 0.005 \\
\hline & {$[1.09]$} \\
\hline Trade credit & 0.024 \\
\hline Cash holdings & {$[1.03]$} \\
\hline & 0.003 \\
\hline Investment & {$[0.09]$} \\
\hline Investment_2 & -0.003 \\
\hline Investment_3 & {$[-0.15]$} \\
\hline & 0.017 \\
\hline Investment_4 & {$[1.13]$} \\
\hline & -0.008 \\
\hline Inefficient investment & {$[-0.42]$} \\
\hline & -0.004 \\
\hline
\end{tabular}

Notes: The Table presents the placebo test, covering the period of 2010-2015 and assuming that the CBRC policy shock occurred in 2012. For each row, column 1 gives the independent variable for Equation (1), and column 2 gives the coefficient of After $\times$ Treated for the corresponding regression. Control variables are included as described in Table 7-11. For variable definitions, see Table 2. Tstatistics are in parentheses and computed using the robust standard error clustered by firm. *,**, and $* * *$ indicate the significance levels at $10 \%, 5 \%$, and $1 \%$ respectively. 


\section{Conclusion}

I use CBRC's credit control policy shock in 2014 as a natural experiment to study the impact of credit supply decline on targeted firms' financing and investment behavior. The specificity and exogeneity of the event allow me to employ the DID approach and IV method to distinguish supply-side force from demand-side one. Evidence shows that the credit supply contraction significantly changes corporate behavior of targeted firms. Affected firms borrowed less not only from banks, but also from bond investors, suppliers and clients. Due to the reduced external funding, they decided to hold less cash and cut down investment.

To better understand the transmission mechanism of the policy shock, I also examine the differential reactions of SOBs and non-SOBs to the regulation, and found that only SOBs executed the policy effectively. I further examine the policy impact on SOEs and non-SOEs separately, and found that all corporate impacts were only significant for non-SOEs, while SOEs were barely affected.

The policy recommendation implied is that Chinese policymakers should consider the uneven capital allocation between SOEs and non-SOEs when applying such credit control policy to the banking system. As the government tries to cure a certain type of preferential credit access (e.g. over-lending to polluting firms), it triggers another type of preferential credit access (e.g. credit rationing to non-SOEs). The lending preference of the banking system distorts the initial purpose of the credit policy, making it a double-edged sword. In this case, fiscal tools such as taxation might be better solutions to the externality problems that governments trying to tackle.

Recent papers focus on the differential impact of 4 trillion RMB stimulus package on SOEs and non-SOEs, while few researchers provide evidence about the discriminating impact of credit contraction policy. The present study fills the gap and completes the whole picture. Completing the findings about the impact of 4 trillion RMB stimulus package, this paper leads to the conclusion that both credit supply increase and credit supply decrease could result in relative capital reallocation from non-SOEs to SOEs. I look forward to future research that examines episodes of sector based credit supply increase policies, and research about how credit policy uncertainty influence the financing and investment of SOEs and non-SOEs differently. 


\section{References}

[1] Allen, F., Jun, Q. and Qian, M. (2005). Law, Finance, and Economic Growth in China. Journal of Financial Economics, 77 (1), 57-116.

[2] Almeida, H. and Campello M. (2002). Financial Constraints and InvestmentCash Flow Sensitivities: New Research Directions. Twelfth Annual Utah Winter Finance Conference.

[3] Banerjee, A.V. and Duflo, E. (2014). Do Firms Want to Borrow More? Testing Credit Constraints Using a Directed Lending Program. Review of Economic Studies, 81 (2), 572-607.

[4] Berg, T. (2018). Got Rejected? Real Effects of Not Getting a Loan. The Review of Financial Studies, 31 (12), 4912-57.

[5] Boyreau-Debray, G. and Wei, S. J. (2005). Pitfalls of State-Dominated Financial System: The Case of China. NBER Working Paper W11214.

[6] Chen, H., Ran, L., and Tillmann, P. (2019). Pushing on a String: State-Owned Enterprises and Monetary Policy Transmission in China. China Economic Review, 54, 26-40.

[7] Chen, K., Patrick H., Waggoner, D. F., and Zha, T. (2016). Impacts of Monetary Stimulus on Credit Allocation and Macroeconomy: Evidence from China. NBER Working Paper W22650.

[8] Chen, K. and Zha, T. (2018). Macroeconomic Effects of China's Financial Policies. NBER Working Paper W25222.

[9] Cull, R. and Xu, L. C. (2003). Who Gets Credit? The Behavior of Bureaucrats and State Banks in Allocating Credit to Chinese State-Owned Enterprises. Journal of Development Economics, 71 (2), 533-59.

[10] Deng, L., Ping J., Li S. and Liao M. (2020). Government Intervention and Firm Investment. Journal of Corporate Finance, 63, 1-19.

[11] Diamond, D. W. (1984). Financial Intermediation and Delegated Monitoring. Review of Economic Studies, 51 (3), 393-414.

[12] Diamond, D. W. (1991). Monitoring and Reputation: The Choice between Bank Loans and Directly Placed Debt. Journal of Political Economy, 99 (4), 689-721.

[13] Duchin, R., Ozbas, O. and Sensoy, B. A. (2010). Costly External Finance, Corporate Investment, and the Subprime Mortgage Credit Crisis. Journal of Financial Economics, 97(3), 418-435.

[14] Fama, E. F. (1985). What's Different about Banks? Journal of Monetary Economics, 15 (1), 29-39.

[15] Faulkender, M. and Petersen, M. A. (2006). Does the Source of Capital Affect Capital Structure? Review of Financial Studies, 19 (1), 45-79.

[16] Firth, M., Chen, L., Liu, P. and Wong, S.M. (2009) Inside the Black Box: Bank Credit Allocation in China's Private Sector. Journal of Banking and Finance, 33, 1144-55.

[17] Holmstrom, B. and Tirole, J. (1997). Financial Intermediation, Loanable Funds, and the Real Sector. Quarterly Journal of Economics, 112 (3), 663-91. 
[18] Hsieh, C. T. and Klenow, P. J.. (2009). Misallocation and Manufacturing TFP in China and India. Quarterly Journal of Economics, 124 (4), 1403-48.

[19] Julio, B. and Yook, Y. (2012). Political Uncertainty and Corporate Investment Cycles. Journal of Finance, 67 (1), 45-83.

[20] Leary, M. T. (2009). Bank Loan Supply, Lender Choice, and Corporate Capital Structure. Journal of Finance, 64 (3), 1143-85.

[21] Lemmon, M. and Roberts, M. R. (2010). The Response of Corporate Financing and Investment to Changes in the Supply of Credit. Journal of Financial and Quantitative Analysis, 45 (3), 555-87.

[22] Lin, W. C., Ponticelli, J., Yang, X. and Gao, H. (2016). Credit Allocation under Economic Stimulus: Evidence from China. Review of Financial Studies, 32(9), 3412-3460

[23] Liu, Q., Pan, X. and Tian, G. (2016). To What Extent Did the Economic Stimulus Package Influence Bank Lending and Corporate Investment Decisions? Evidence from China. Journal of Banking and Finance, 86, 177193.

[24] Modigliani, F. and Merton, H. M. (1958). The Cost of Capital, Corporation Finance, and the Theory of Investment: Reply. American Economic Review, 48 (3), 261-97.

[25] Rajan, R.G. and Zingales, L. (1995). What Do We Know about Capital Structure? Some Evidence from International Data. Journal of Finance, 50 (5), 1421-60.

[26] Richardson, S. (2006). Over-Investment of Free Cash Flow. Review of Accounting Studies, 11 (2), 159-89.

[27] Song, Z., Storesletten, K. and Zilibotti, F. (2011). Growing like China. American Economic Review, 101 (1), 196-233.

[28] Yi, G. (2020). Revisiting China's Financial Asset Structure and Policy Implications. Economic Research Journal, 55 (3), 4-17. 